VOLUME 17 NOMOR 03, JULI 2018

\title{
PEMBINAAN KEPARIWISATAAN MELALUI PELATIHAN ETIKA PELAYANAN PEKERJA WANITA DI ART SHOP DESA ADAT SEMINYAK KABUPATEN BADUNG
}

\author{
Putu Diah Kesumadewi ${ }^{1}$, Ni Made Ariani ${ }^{2}$, A.A Manik Pratiwi ${ }^{3}$, dan Putu Sucita Yanthy ${ }^{4}$
}

\begin{abstract}
The tourism industry is very fast growing nowadays in Desa Adat Seminyak. One of the tourism industries that supports the existence of tourism in Desa Adat Seminyak is the art shop. The existence of art shop invites tourists who visit the area of Seminyak and surrounding areas to shop for various needs at the venue. Usually goods purchased by tourists to be brought as a fruit hand to place of origin. Not infrequently tourists also shop at the art shop for business purposes, because the goods purchased can also be resold in the area of origin. The Art shop in Desa Adat Seminyak is expected to benefit the local community in this village. Therefore most workers are expected to come from the village. Most art shop workers in Desa Adat Seminyak are female workers. This is because working in the art shop does not require heavy power and can set the time because it is not bound by the work time. Female workers are considered very suitable to work in the art shop because it has good selling ability. But not just the ability to sell that must be owned by female workers, another ability that must be owned by female workers is the ability to serve consumers in this case tourists. Good service is needed by female workers so that tourists can comfortably shop at the art shop in Desa Adat Seminyak. One way that can be done to implement good service by female art shop workers is by providing training of service ethics to these workers. The service ethics training model that can be applied to female workers in art shop is in various ways, such as the ethics of foreign-language communication, good-looking ethics and good conduct ethics. Through this devotion is expected to form a good service ethics to female art shop workers so that the quality of service can be good. Good service quality is expected to be able to make a positive impact for the existence of tourism in Desa Adat Seminyak.
\end{abstract}

Keywords: Service ethics, female workers and Art Shop

\section{PENDAHULUAN}

\subsection{Analisis Situasi}

Desa Adat Seminyak merupakan desa adat yang berlokasi di Kelurahan Seminyak, Kecamatan Kuta, Kabupaten Badung. Kelurahan Seminyak terdiri atas dua banjar yaitu Banjar Basangkasa yang

\footnotetext{
${ }^{1}$ Program Studi D-IV Pariwisata Fakultas Pariwisata, Universita Udayana, diawengirl1235711@yahoo.com

${ }^{2}$ Program Studi D-IV Pariwisata Fakultas Pariwisata, Universita Udayana, ayukariani97@yahoo.co.id

${ }^{3}$ Program Studi D-IV Pariwisata Fakultas Pariwisata, Universita Udayana, agungmanik89@gmail.com

${ }^{4}$ Program Studi D-IV Pariwisata Fakultas Pariwisata, Universita Udayana, putusucitayanthy@yahoo.com
} 
warganya masuk Desa Adat Kerobokan dan Banjar Seminyak yang warganya masuk Desa Adat Seminyak. Desa Adat Seminyak merupakan salah satu desa adat di Bali yang sangat mendukung perkembangan pariwisata di wilayah Bali. Salah satu bentuk dukungan terhadap perkembangan pariwisata di Bali ditunjukkan dengan keterbukaan masyarakat Desa Adat Seminyak terhadap perkembangan pariwisata di wilayah desa ini. Keterbukaan masyarakat membawa dampak yang positif bagi perkembangan pariwisata di Desa Adat Seminyak.

Dampak positif yang dapat diberikan dari perkembangan pariwisata di Desa Adat Seminyak salah satunya pada bidang ekonomi. Ini ditunjukkan dengan Banyaknya industri pariwisata yang berkembang seiring dengan perkembangan pariwisata di kawasan ini. Industri pariwisata merupakan kumpulan usaha pariwisata yang saling terkait dalam rangka menghasilkan barang dan/atau jasa bagi pemenuhan kebutuhan wisatawan dalam penyelenggaraan pariwisata (Undang-Undang Pariwisata no 10 tahun 2009). Salah satu industri pariwisata yang mendukung keberadaan pariwisata di Desa Adat Seminyak adalah art shop. Art shop diharapkan menjadi industri pariwisata yang dapat memberikan keuntungan bagi masyarakat lokal Desa Adat Seminyak. Maka dari itu kebanyakan pengelola art shop berasal dari Desa Adat Seminyak dan sekitarnya.

Keberadaan art shop mengundang wisatawan yang berkunjung ke daerah Seminyak dan sekitarnya untuk berbelanja berbagai kebutuhan di tempat tersebut. Biasanya barang-barang yang dibeli oleh wisatawan untuk dibawa sebagai buah tangan ke tempat asalnya. Tidak jarang wisatawan juga berbelanja di art shop untuk keperluan bisnis, karena barang yang dibeli juga dapat dijual kembali di daerah asalnya.

Art shop di Desa Adat Seminyak diharapkan mampu menguntungkan bagi masyarakat lokal di desa ini. Oleh karena itu kebanyakan pekerja diharapkan berasal dari desa tersebut. Kebanyakan pekerja art shop di Desa Adat Seminyak merupakan pekerja wanita. Ini disebabkan karena bekerja di art shop tidak membutuhkan tenaga yang berat serta dapat mengatur waktu karena tidak terikat oleh waktu kerja. Pekerja wanita dirasa sangat cocok untuk bekerja di art shop karena memiliki kemampuan menjual yang baik. Namun tidak hanya kemampuan menjual yang harus dimiliki oleh pekerja wanita, kemampuan lain yang harus dimiliki oleh pekerja wanita adalah kemampuan melayani konsumen dalam hal ini wisatawan. Pelayanan yang baik dibutuhkan oleh pekerja wanita agar wisatawan dapat nyaman berbelanja di art shop di Desa Adat Seminyak ini. Salah satu cara yang dapat dilakukan untuk menerapkan pelayanan yang baik oleh pekerja wanita art shop adalah dengan memberikan pelatihan etika pelayanan kepada pekerja ini.

Etika, menurut bahasa (etimologi) istilah berasal dari bahasa Yunani, yaitu ethos yang berarti adatistiadat (kebiasaan), perasaan batin, kecenderungan hati untuk melakukan perbuatan atau mengajarkan tentang keluhuran budi baik- buruk. (Abdulllah, 2006). Menurut Kotler dalam Laksana (2008) pelayanan adalah setiap tindakan atau kegiatan yang dapat ditawarkan oleh suatu pihak kepada pihak lain, yang pada dasarnya tidak berwujud dan tidak mengakibatkan kepemilikan apapun. Model pelatihan etika pelayanan yang dapat diterapkan kepada pekerja wanita di art shop adalah dengan berbagai cara, seperti etika komunikasi berbahasa asing, etika berpenampilan yang baik serta etika berperilaku yang baik. Melalui pengabdian ini diharapkan dapat membentuk etika pelayanan yang baik kepada pekerja wanita art shop sehingga kualitas pelayanan dapat menjadi baik. Kualitas pelayanan yang baik ini diharapkan mampu untuk membuat dampak yang positif bagi keberadaan pariwisata di Desa Adat Seminyak. 


\subsection{Tujuan Kegiatan}

Tujuan kegiatan ini adalah untuk memberikan pengetahuan serta keterampilan bagi pekerja wanita art shop mengenai tata cara etika pelayanan yang baik sehingga akan memberikan kualitas pelayanan yang baik dalam melayani tamu yang berkunjung ke art shop di Desa Adat Seminyak. Kualitas pelayanan yang baik akan mendukung keberadaan pariwisata yang ada di Desa Adat Seminyak.

\section{METODE PEMECAHAN MASALAH}

Manfaat yang diharapkan dari pengabdian kepada masyarakat ini adalah:

1. Kegiatan ini sangat bermanfaat bagi pekerja wanita art shop di Desa Adat Seminyak untuk dapat menambah pengetahuan mengenai tata cara etika pelayanan

2. Bermanfaat bagi pekerja wanita untuk dapat menambah keterampilan mengenai tata cara etika pelayanan yang baik sehingga akan memberikan kualitas pelayanan yang baik dalam melayani tamu yang berkunjung ke art shop di Desa Adat Seminyak.

3. Memberikan pemahaman kepada wanita pekerja art shop akan pentingnya menerapkan etika pealayan yang baik saat melayani tamu yang berkunjung.

4. Memberikan acuan agar tercipta kualitas pelayanan yang baik sehingga akan mendukung keberadaan pariwisata yang ada di Desa Adat Seminyak.

Pelaksanaan kegiatan pengabdian masyarakat bagi pekerja wanita di Art Shop Desa Adat

Seminyak diawali dengan proses penjajagan kepada Kepala Lingkungan seminyak. Kegiatan ini lebih menekankan pada pelatihan dalam meningkatkan kualitas pelayanan pekerja wanita art shop di Desa Adat Seminyak, Kabupaten Badung. Pelaksanaan kegiatan pengabdian masyarakat yang dilakukan oleh Tim Dosen Fakultas Pariwisata Unversitas Udayana dapat dikatakan berhasil karena indikator sasaran dan tujuan yang diharapkan dapat tercapai. Peserta pelatihan dalam hal ini pekerja wanita art shop di Desa Adat Seminyak sangat antusias dalam mengikuti pelatihan etika pelayanan ini. Pekerja wanita art shop ini mengikuti pelatihan ini dengan baik.

\section{HASIL DAN PEMBAHASAN}

\subsection{Etika Pelayanan}

Etika Pelayanan merupakan salah satu hal yang harus diperhatikan dalam melayani pelanggan. Bertens (2000) berkesimpulan bahwa ada tiga arti penting etika, yaitu etika (1) sebagai nilai-nilai moral dan norma-norma moral yang menjadi pegangan bagi seseorang atau suatu kelompok dalam mengatur tingkah lakunya, atau disebut dengan "sistim nilai"; (2) sebagai kumpulan asas atau nilai moral yang sering dikenal dengan "kode etik"; dan (3) sebagai ilmu tentang yang baik atau buruk, yang acapkali disebut "filsafat moral". Dilihat dari pentingnya etika untuk diterapkan dalam mengatur tingkah laku seseorang, maka hal ini penting untuk dijadikan pedoman dalam melayani pelanggan.

Adapun beberapa pelatihan yang diberikan untuk meningkatkan etika pelayanan pekerja wanita art shop di Desa Adat Seminyak, antara lain:

1. Hal-Hal Yang Berkaitan Dengan Etiket

Pelatihan ini dilakukan dengan tujuan memperkenalkan hal-hal yang berkaitan dengan etika;

- Cara duduk

- Cara duduk yg baik bagi wanita adalah duduk rapi dgn lutut dirapatkan

- Duduklah agak menyerong dengan kedua tangan di atas pangkuan 
- Jika duduk satu deret dgn lawan bicara, duduklah sedikit menyerong ke arah lawan bicara untuk menimbulkan kesan anda memperhatikan lawan bicara

- Jika kita berbicara dgn orang asing tataplah wajah dan mata lawan bicara ini menunjukkan anda bersikap jujur kepada mereka

- $\quad$ Sikap di tempat-tempat umum

- Hindari penggunaan barang pribadi secara berlebihan (perhiasan, aksesoris, make up, dll.)

- Berpakaian sederhana, rapi, bersih, serasi, dan sesuai situasi

- Wanita hendaknya turun tangga mendahului pria (asalkan tangga tidak curam dan licin)

- Waktu naik tangga pria hendaknya naik terlebih dahulu

- Apabila anda diundang dalam sebuah pertemuan, resepsi, perjamuan yang ada kaitan dgn anda janganlah bersikap sebagai tamu sebaliknya bersikap sebagai tuan rumah (membantu tamu lain)

- Jangan bergerombol dgn orang-orang yang dikenal, berusahalah membaur

- Jika mengajak pasangan/orang lain perkenalkanlah kepada tamu yang lain

- Kita boleh memberikan kritik terhadap seseorang asalkan bijaksana tidak mencolok dan di depan umum

- Berbicaralah dengan bahasa yang bisa dimengerti oleh semua orang, misal pertemuan dengan orang asing gunakanlah bahasa inggris, pertemuan dengan orang indonesia menggunakan Bahasa Indonesia

\subsection{Etika dalam Bekerja di Industri Pariwisata dalam Hal Ini Art Shop di Desa Adat Seminyak}

Pelatihan etika bekerja pada industri pariwisata dalam hal ini art shop oleh perempuan Bali sangat diperlukan untuk menunjang pelayanan pada industri ini. Beberapa langkah yang terkait etika pelayanan sebagai acuan perempuan Bali bekerja di art shop Desa Adat Seminyak antara lain:

1. Mengucapkan salam

Pengucapan salam harus dilakukan dalam menyambut tamu yang datang ke art shop. Pengucapan salam disampaikan sesuai waktu, apakah pada pagi hari, siang hari atau malam hari serta dikondisikan pada tamu yang datang apakah tamu domestik atau tamu mancanegara. Contoh : Selamat Pagi Bapak/Ibu, ada yang dapat saya bantu? atau Good Morning Sir/Madam, how may I help you?

2. Perkenalan

Memperkenalkan diri kepada tamu yang datang dapat membuat suasana menjadi akrab dan nyaman bagi tamu. Sikap yang dilakukan pada saat memperkenalkan nama kepada tamu adalah dengan berdiri tegak serta dengan menampilkan mimik wajah yang bersahabat. Contoh: Perkenalkan nama saya Diah, saya akan membantu anda untuk mendapatkan sesuatu yang anda inginkan atau My name is Diah, I will assist you to get anything that you want, Sir/Madam?

3. Loyalitas

Diperlukan loyalitas dalam melayani tamu agar tamu merasa nyaman dan senang berkunjung ke art shop tersebut. Loyalitas yang dimaksud adalah tidak menempatkan kepentingan pribadi di atas kepentingan pelanggan dalam hal ini tamu. Dengan sikap yang loyalitas terhadap pekerjaan akan membuat perempuan Bali dipandang baik oleh pelanggan sebagai pekerja yang beretika.

4. Ikut menempatkan diri pada sisi pelanggan

Sebagai pekerja art shop harus pandai memahami maksud pelanggan dalam hal ini tamu. Maksud yang diingikna oleh tamu dapat diketahui dengan cara berkomunikasi secara baik dan benar. Untuk itu perlu dikuasai tehnik berkomunikasi yang baik. Misalnya dengan memandang wajah tamu dan 
memperhatikan mimik wajah tamu. Apabila tamu menunjukkan mimik wajah yang bahagia dan senang berarti dia puas atas pelayanan yang telah diberikan. Maka sepatutnya dilanjutkan untuk menawarkan barang-barang yang diinginkan oleh tamu tersebut. Namun jika raut wajah tamu menunjukkan kesan yang tidak bahagia berarti tamu tersebut tidak menginginkan atas barang yang ditawarkan sehingga dilakukan penawaran atas barang yang lainnya. Menempatkan diri pada sisi pelanggan akan membuat pelayanan yang dilakukan akan menjadi baik sehingga akan berdampak baik atas penjualan nantinya.

5. Menutup penjualan dengan baik

Setelah tamu selesai melakukan pemebelian di art shop, maka diperlukan teknik penutupan penjualan yang baik. Karena teknik ini akan berdampak akan kunjungan tamu berikutnya. Tamu yang berkesan baik atas pelayanan yang didapatkan akan kembali berkunjung ke art shop tersebut. Repeater guest tidak hanya dimiliki oleh sektor perhotelan saja namun ada kalanya dimiliki oleh sektor industri pariwisata lain dalam hal ini art shop. Gunakan kata-kata manis dalam menutup penjualan seperti: Terimakasih atas kunjungannya semoga hari ini menyenangkan atau thakl you for coming, have a great day.

\subsection{Manfaat Mempelajari Etika Pelayanan}

Pelatihan bagaimana manfaat mempelajari etika pelayanan pekerja wanita art shop di Desa Adat Seminyak antara lain dapat menjaga hubungan baik antar pekerja wanita art shop di Desa Adat Seminyak dengan sesama manusia antara lain dengan sesama pekerja maupun dengan pelanggan dalam hal ini tamu yang bverbelanja. Selain itu diharapkan pekerja art shop mampu berprilaku sopan, ramah bersahabat dengan siapa saja yang berhubungan dengan mereka. Merka juga diharapkan mampu senantiasa membantu dan mampu menjaga perasaan orang lain di sekitar mereka. Pelatihan ini juga diharapkan mampu menempatkan mereka pada siatuasi dan kondis yangbaik serta mampu menyelesaikan masalah dengan cara yang baik. Pekerja wanita art shop diharapkan dapat meningkatkan rasa percaya diri mereka sehingga dalam melayani pelanggan dalam hal ini tamu, mereka akan dapat melakukan pekerjaannya dengan menggunakan kemampuan mereka yang maksimal.

Etika pelayanan pekerja wanita di art shop di Desa Adat Seminyak merupakan hal yang penting dalam menunjang pelayanan bagi wisatawan yang berkunjung ke Desa Adat Seminyak. Dengan memberikan pelayanan yang baik melalui penerapan etika pelayanan yang baik akan membuat wisatawan yang berkunjung menjadi nyaman berkunjung ke art shop di Desa Adat Seminyak. Oleh sebab itu, diharapkan pekerja wanita dapat terus memberikan etika pelayanan yang baik dalam melayani tamu yang berkunjung. Untuk menjamin keberlanjutan program ini maka Tim Udayana Mengabdi Fakultas Pariwisata, Universitas Udayana akan melakukan pendampingan secara berkelanjutan agar program ini dapat berjalan dengan baik. Pendampingan direncanakan berlangsung selama 3 tahun melalui sosialisasi, pelatihan dan monitoring/evaluasi. Partisipatif aktif pekerja perempuan sangat diharapkan untuk menunjang program ini agar etika pelayanan dapat dilakukan dengan baik.

\section{KESIMPULAN DAN SARAN}

\subsection{Simpulan}

Kegiatan pengabdian masyarakat ini berjalan dengan lancar karena materi yang disampaikan sangat menarik terlebih lagi kegiatan utama yang dijadwalkan yakni pembinaan kepariwisataan melalui pelatihan etika pelayanan pekerja wanita arts shop sangat dibutukkan oleh pekerja tersebut. Kegiatan 
pengabdian ini berjalan dengan baik dan para peserta pelatihan sangat antusias dalam mengikuti materi yang diberikan. Adapun materi yang diberikan dalam acara pengabdian yaitu Pelatihan Hal-Hal Yang Berkaitan dengan Etika serta Pelatihan Manfaat Mempelajari etika Pelayanan pekerja wanita di Desa Adat Seminyak.

\subsection{Saran}

Disarankan agar adanya suatu sinergi baik antara pemerintah, pengelola art shop, maupun masyarakat Desa Adat Seminyak untuk selalu meningkatkan perannya di dalam penggunaan etika pelayanan dalam kehidupan sehari-hari. Hal ini penting dilakukan untuk lebih mengembangkan potensi pariwisata khususnya industri pariwisata art shop di Desa Adat Seminyak.

\section{DAFTAR PUSTAKA}

, Undang-Undang No. 10 Tahun 2009 Tentang Kepariwisataan

Abdullah, M.Yatimin. 2006. Pengantar Studi Etika. Jakarta: PT. Rajagrafindo Persada

Bertens, K. 2000. Etika. Seri Filsafat Atma Jaya: 15. Jakarta: Penerbit PT Gramedia Pustaka Utama.

Fajar, Laksana. 2008. Manajemen Pemasaran. Edisi Pertama. Yogyakarta: Graha Ilmu 